Psychology of Language and Communication 2018, Vol. 22, No. 1

DE GRUYTER

OPEN

DOI: $10.2478 /$ plc-2018-0007

GRZEGORZ GRZEGORCZYK

University of Gdańsk, Poland

\title{
DIALOGUE AND LANGUAGE AS FACTORS CONTRIBUTING TO TRANSFORMATIVE LEARNING IN ACADEMIC TUTORING
}

\begin{abstract}
Among a number of teaching practices, personalized education is gaining in popularity owing to its enticing appeal of a novel, humanistic attitude with unparalleled pedagogical results unlike those observed in traditional standardized mass education models. As part of the fourth moment in the history of education (according to the timeline in Davis, Sumara and Kapler, 2015), personalized education under the guise of tutoring or educational coaching is boldly re-entering schools and the academic world. Observing the daily practices of tutors and educational coaches on various levels of schooling, we can note a number of features which contribute to the emergence of a model where learning becomes an autonomous, lived experience. In this model communication is understood as a collaborative dialogical practice, which leads us to see learning as a result of interactivity in the learner-tutor dyad afforded by geo-spatial conditions, physio-psychological elements and language. All these contribute to the occurrence of transformative results as evidenced in student post-tutoring narratives. In this paper we present learning in the dialogical tutor-tutee paradigm as a distributed, embodied, and enacted meaning-making process rather than mere 'sending' and 'receiving' of substantive information (e.g., De Jaegher and DiPaolo, 2007; Neuman and Cowley, 2013). Described as such, the method fits in the paradigm of self-regulated learning. We therefore postulate the claim that personalised education as exemplified by tutoring is co-agential and prompts learning on multiple timescales. Consequently, cognition and learning in tutoring is enactment of knowledge, while coordinating speech rather than knowledge transmission.
\end{abstract}

Key words: interactivity, learning, language, embodiment, meaning-making

Address for correspondence: Grzegorz Grzegorczyk, Department of Applied Linguistics and Translation Studies, University of Gdańsk, Bażyńskiego 8, 80-309 Gdańsk, Poland. E-mail: grzegorz.grzegorczyk@ ug.edu.pl 


\section{Introduction}

The volume of practical experience in the area of personalised education is constantly increasing. The variety of insights, observations, reflections or practices within this abundance is, as can be observed, characterised by lack of systematic approach and, sometimes mutual exclusivity. With scant empirical evidence we are still far from understanding precisely how language the behaviour of both tutor and student correlates with cognition and learning on the part of the latter. Neither do we know how it might be generalised across other types of dialogical educational practices, such as coaching, mentoring or some therapeutic forms (e.g., Acceptance and Commitment Therapy, Rational Behaviour Therapy or Motivational Interviewing). It is our objective here to add one more element to this picture by focusing on language as a vital aspect of situational context in tutoring as a form of academic supervision and coaching. This theoretical reflection based on a selection of fragmentary observations from the results of a comprehensive survey, as well as excerpts from tutoring sessions might assist in clarifying what happens between tutor and student/tutor. The approach adopted here should also provide a broader picture of the area under scrutiny by drawing on an alternative understanding of language, interaction and dialogue. By adding together cases of individual experience expressed in reports gathered after tutoring processes, we will discuss and interpret the relationships between facts that we observe in tutoring conversations. Our ambition in this text will be to merge the insightful, yet fragmentary portions of data into a more comprehensive piece of evidence, thus forming a more theoretical overview of what happens in educational personalised conversations, which offers a starting point for further research and debate.

\section{Effects of personalised education - a case reference}

Among a palette of different configurations which dialoguing agents can enter in the educational setting, we are specifically interested in the studentteacher dyad in the distinctive environment of a tutorial, namely, a studentteacher instructional meeting based on a task, usually an essay, previously prepared by a student. Some of the points of a tutorial agenda include student reflections on the contents and process of writing followed by an attempt at self-assessment and working out strategies of critical and analytical thinking. A full educational process encapsulates a series of seven to ten tutorials linked in terms of recurring theme, negotiated aims (both knowledge, skills and competences) and outcome material. A 2015-2016 survey by Karpińska-Musiał (2016) suggests that from the point of view of tutors, students display progress in terms of their grasp of the material studied, topic awareness, perception of detail, reasoning and judgment (critical thinking). Considering the above, we define tutoring as a non-instructive dialogical practice of the mind which, in 
the course of a series of one-to-one, face-to-face encounters between student/ tutee and teacher/tutor, addresses the unlimited autonomy of the individual by establishing a co-agential sense-making dialogical relationship in the arena of language. As such, tutoring offers an array of opportunities encompassing both academic learning and personal development. Consequently, tutoring constitutes an interesting example of a transformative interaction based on language and affording sense-making processes. As it is impossible to make sense non-dialogically, we consider the dialogical, two-person situational context present in tutoring as the most natural environment for learning agents in Mezirow's words "[w] can try out another person's point of view and appropriate it, but we cannot do this with a habit of mind. Points of view are more accessible to awareness and to feedback from others" (Mezirow, 1997, p. 6).

The outcomes indicative of transformation include Cranton's (1992) framework of three types of change: change in assumptions, change in perspective, and change in behaviour. Boyd (1989) adds that the outcome of transformative learning also features a change in self. This finds confirmation in the research carried out at the University of Gdańsk on a sample of 222 students who took part in the innovative educational project called $W$ trosce o jakość w ilości-program interdyscyplinarnego wspierania studenta filologii obcej w oparciu o metodę tutoringu akademickiego w Uniwersytecie Gdańskim (IQ) (Ideal Quality in Good Quantity -interdisciplinary support programme for students of foreign language studies based on academic tutoring at the University of Gdańsk). Following their participation in a series of one-toone tutorials (1600 hours in total) offered by a group of 31 trained academic tutors, both groups completed survey questionnaires where they were asked to deliberate on the nature and effects of their experience (Karpińska-Musiał, 2016). Ninety-eight percent of the participants considered the goals of their educational processes as accomplished. Nearly $57 \%$ of all students indicated establishing of personalised and dialogical relationship as the key success factor, while over $47 \%$ saw the type of tutor-student relationship as conducive to learning. The affective aspect was equally significant as students found their learning process dynamical, emotional and based on surprise (Karpińska-Musiał, 2016).

Tutors in their narratives as expressed in post-project questionnaires signal the importance of group learning. Karpińska-Musiał (2016, p. 196-197) notes that the constructing and reconstructing of students' mental models occurs in the dialogical space. Conditions include surprise and mutuality of inspiration and learning. From this it may be concluded that transformative learning as observed in tutorials is rooted in the communicative coordination of two agents concerting speech within the institutional framework of a tutoring conversation. The tutoring conversation requires argumentative skills and the ability to ask and respond to thoughtful questioning. 
This conversational framework seems to provide an environment conducive to cognitive transformational processes. The kind of intellectual and sometimes affective challenges that students are invited to confront (also commented upon in post-tutoring narratives, e.g., Karpińska-Musiał, 2016) invite both participants to examine their personally-held views and perspectives and require them to determine the validity of their beliefs about the phenomena and topics under discussion. A number of student-tutees saw the value of these practices in the attempt they made to change their mindset. The survey results accentuate the significance of learning and the students' journey towards their personal mastery. From this we infer that what tutoring offers is an opportunity for a conversation through which transformation occurs by engaging the student in a dialogical sense-making activity. In other words, the reported effects of tutoring seem to be ontogenetically contingent on interactivity or sense-saturated coordination (as in Steffensen, 2013) and first order languaging understood as an activity where wordings play a part (Cowley, 2015). Talk in tutoring provides the necessary context for what Mezirov refers to as transformative learning. Tutoring conversation can then be perceived as a space where the student-tutee ventures to (re)create his/her mental models and consequently experience change on a number of levels. Learning in tutoring is thus collaborative, dialogical and language-based.

\section{Transformative learning through sense-making in conversations}

Transformative learning is the theoretical framework within which we see the effects of personalised education as evidenced in tutoring, instructional coaching and academic supervision processes. The theory proposed by Mezirow $(1991,1997,2000)$ stipulates that an adult learner transforms within his/her frame of reference which in turn leads to liberation from unreflective, unmindful and unthinking approaches to interpreting experience by means of solidified and dysfunctional sense-making strategies. Transformative learning is

the expansion of consciousness through the transformation of basic worldview and specific capacities of the self; transformative learning is facilitated through consciously directed processes such as appreciatively accessing and receiving the symbolic contents of the unconscious and critically analyzing underlying premises (Elias, 1997, p. 3).

The end product of transformational learning is change in the ways a learning agent interprets the self and the world around, which leads to the development of new strategies for refining the surrounding reality. The core of this process is for Mezirow a transformation in the individual frame of reference which he defines as "the structures of assumptions through which we understand our experiences ... They selectively shape and delimit expectations, perceptions, cognition, and feelings" (Mezirow, 
1997, p. 5). The frame of reference provides context for sense-making as a construction, helping learners interpret their world and their experience in it. As such it influences agents' thinking paradigms, ways of affect and activities (Mezirow, 2000). In this manner, "actions and behaviors will be changed based on the changed perspective" (Cranton, 1994, p. 730). The process consists in constructing new methods of handling sense-making in relation to personal experience or in separating what one accepts unthinkingly and habitually in daily interactions with the world from one's own activity pivoting on conscious and critical reflection. As Mezirow points out, "learners need practice in recognizing frames of reference and using their imaginations to redefine problems from a different perspective" (Mezirow, 1997, p. 10). This transformation is a three-step process on the timescale extending beyond the duration of the tutoring process. Firstly, we observe changes in learners' understanding of their own selves, then in their belief systems which may undergo revision, and finally in changes their cognitive behaviour. These psychological, convictional and behavioural results of tutoring are reflected in some of students' narratives as evidenced in Karpińska-Musial's (2016) research. The changes students reported concerned academic skills improvement, increased motivation for studying, self-confidence, beliefs about their knowledge and study skills, social attitudes or identity as a student.

In attempting to pinpoint the source of the transformation evidenced by students' narratives, we turn again to Mezirow and some followers like Robertson (1997), who highlight the presence of 'the other' as a prerequisite for establishing a trusting, social context for the dialogue referred to as reflective (Mezirow, 2000) or critical discourse (Grabove, 1997). Transformative learning is through "dialogue involving the assessment of beliefs, feelings, and values" (Mezirow, 2003, p. 59). As dialoguing agents become immersed in language, this factor emerges on the one hand as a crucial component of the transformational context, and on the other as an underdeveloped aspect of Mezirow's theory. In order to assign it proper consideration, we need to focus on talk as a series of events, doings, happenings, feelings and states instigated and experienced by both interacting agents, that is the educator (tutor, coach, supervisor) and the learner (student/tutee) in the course of tutoring conversation. Subsequent to this is constructing a description of education founded on interactivity, sense-making and specifically arranged dialogue. The tutoring dialogue (which we may refer to as an educational dialogue) falls into the category of institutional talk with its idiosyncratic linguistic modality pivoting on questions asked by the tutor. The prime objective of educational dialogue is teaching through participation where learning tasks are structured as open questions (this will be elucidated in the two extracts discussed further in the text). Answers are elicited as pragmatically and rationally possible rather 
than as prescriptively correct, which stems from the premise that the student should be invited to actively interact with the tutor on the subject matter as they engage in conversation. Such a structure leads to learning through appropriation. In this description we hear an echo of what occurs in problem-solving interactional situations, where the actual process of sensemaking unfolds in the arena of language (as in Steffensen, 2013). Learning a particular content is merely a constantly verified local objective, which, rather than an end in itself, appears to be the means to the end result of enhanced cognition. The skill of conversing about the content related to an agent's experience increases the chances of arriving at the outlined purpose through performing learning tasks dialogically.

The notion that learning is dialogic has been well developed in other important lines of work (e.g., Matusov, 2009, Mercer \& Littleton, 2007, Wells 1999). By observing personalised education methods, we obtain a fine-grained picture of what dialogical learning involves in detail. Tutoring as a practice occurring at the pre-contemplative level emerges as a bodily activity serving as a cognitive scaffolding. This is because cognition is not located in the agent's head but only emerges through an agent's interaction with the artefacts in the agent's physical environment (Hutchins, 1995). The physical environment in this case is language as a combination of wordings and physical dynamics. By acknowledging the embodied aspect of language as the physical environment for tutoring, we elevate the role of talk-in-interaction from a mere backdrop to learning to an integral part, with tutor and the student/tutee as agents co-creating their learning environment by talking to each other. It is interesting how this environment emerges and why, according to our hypothesis, it contributes significantly to cognitive and behavioural transformation. Pursuing this interest we observe, following Davis, Sumara, and Kieren (1996, p. 153), that "learning should not be understood in terms of a sequence of actions, but in terms of an ongoing structural dance a complex choreography - of events which, even in retrospect, cannot be fully disentangled and understood, let alone reproduced". It transpires that dialogue forms the substrate for the type of learning where interacting agents are inseparable in their co-constructing of educational reality. In this we see confirmation of Batesonian understanding of knowledge as action (cf. Bateson, 1973). The position developed here is informed by two perspectives which might lead us to a location from which the view becomes less obscure.

The first perspective takes us to Varela, Thompson and Rosch's (1991) concept of cognition understood not as a representation of a pre-given world but as enactment of the world and mind based on histories of various activities. The framework of tutoring conversation provides adequate space for this sense-making process to occur. By adopting the dialogic inquiry orientation, the participants organise their experience of the world as they talk. As a result, they co-construct new models of knowledge, beliefs or 
behaviour dialogically. This dynamic dyadic operation couples them in a communicative act of co-ordinating mutual cognitive domains as they turn to first-order languaging. This is redolent of what De Jaegher and Di Paolo call participatory sense-making (De Jaegher and Di Paolo, 2007; Fuchs and De Jaegher, 2009). In their conception, meaning is made and processed in an interplay between unfolding interaction and its participants because, any dialogical (in the Bachtinian sense) interaction calls for sense-making. In academic practice sense-making results from an interaction between construction and critique which clarifies why the same is reproduced for individuals (as in Vygotsky, 1978).

The second perspective is language understood as an activity rather than a code or system of signs. We follow Maturana's concept of languaging (Maturana, 1970) as a social activity where the process of coordination of actions leads to mutual adaptation of talking agents. The heterogeneity and variety that we observe in "first-order languaging" (Thibault, 2011) allows us to see it as a meshwork which is the sum of its parts, as in the distributed approach. The linguistic activity is prerequisite for cognition to occur as it coordinates communicative actions on multiple timescales (Cowley, 2010). Again we can see that the significance of language is not in its mediating function but in that it primarily becomes a physical and empirical domain of communication in which processes of semiotic mediation are instigated. At the same time, we can see language in tutoring as revealing the characteristic traits of a lived phenomenon and a real occurrence. Languaging can also be seen as a process of negotiating and producing meaningful, comprehensible output as part of learning (cf. Swain, 1985). This directs us towards what Fogel (2009, p. 29) calls co-regulation or "continuous unfolding of individual action that is susceptible to being continuously modified by the continuously changing actions of the partner." An important aspect of this idea is that co-regulation is irreducible to the behaviours or experiences of the individuals involved in the interaction. The interaction arises as each participant repeatedly regulates the behaviour of the other. It is a continuous and dynamic process, rather than the exchange of discrete information.

As can be inferred from the above, the activity of talking to each other in tutoring serves the function of organising the experience of discussing ideas and induces change on a number of levels: knowledge, awareness, and behaviour. It is Tutee's experience and the process of its mental integration which constitutes the prime goal of tutorials. Therefore, students/tutees are in a process of constant seeking in the area of awareness, self, context and interaction. This search takes place in the arena of language. 


\section{Question-based dialogue as a framework for transformative learning}

In an attempt to theorise on the observable practice of a tutoring conversation, we define dialogue as a form of socially organised interaction based in the arena of language.

For Linell (1998) a dialogue is any dyadic or polyadic interaction between individuals interacting through language or other symbolic means. Immersion in dialogue and the foundation of a relationship thereon leads to the emergence of dialogicality which, for Markova (2003) is the environment for an individual's change to occur. The transformative power of tutoring dialogue lies in its Socratic bias towards discovery through questions on which it builds its potential for private appropriation in the process of reflection induced by co-orchestrated sense-making. The value of questions is however reinforced by the basic features of multiscalarity and non-locality. Its micro-macro interface presenting itself as micro-situational context is linked to the broader macroscale of knowledge, culture and history equally important for each interactant. The tutor-tutee micro-system is part of the whole distributed cognitive system which paves the way for scanning a larger perspective: how this affects those around them, the relations to historical norms, culture and their personal histories and the rules of coaching. This is a classic example of the non-local exerting a massive effect.

A conversing dyad naturally co-constructs a dialogue exhibiting characteristics associated with learning. This places one-to-one tutoring conversations in the category of institutional talk. A paradigmatic tutoring dialogue usually begins with an opening typical of daily conversation. Afterwards the student/tutee presents a produced essay or an answer to a task prescribed by the tutor in the previous meeting. The tutor then reviews the essay inviting the student to critically assess selected elements. The ensuing conversational exchange is characterised by tutor's cues in the form of questions building on the essay/task material and posing qualitative problems connected with the theme of the tutorial. The motivation here is to broaden the student's perspective and construct alternative ways of reasoning about the problem discussed in the task. These are followed by more or less extended replies from the student addressing the core issues and expressing views and opinions. In brief, what we can observe here is the tutor engaging the student/tutee in spoken reflective dialogue with the aim to provide an opportunity for critical thinking. They both continue to correct possible misconceptions and elicit more complete explanations. A tutoring session ends with both interactants summing up their conversation and the tutor setting a new task for the student to prepare for the next meeting.

Described as above, tutoring appears as a case of dialogue with educational purposes and transformative outcomes and as such may be 
classified as an emanation of dialogical education. Matusov and Miyazaki (2014) describe genuine dialogical education as dialogical-ontological rather than instrumental or epistemological, which places tutoring in the area of processes aimed at transforming the whole person, with learning becoming an inseparable part of life, in addition to a mode of life:

Ontological dialogue generates its own unfinalized dialogic values by searching for and testing ideas and values against other ideas and values ... Ontological dialogue has its own dialogic value in itself as the inherently valuable way of being, non-reducible to any other ways of being. (Matusov and Miyazaki, 2014; http:dpj.pitt.edu)

The student's new experience and the ensuing integration process are in the focus and the target of the tutoring process, which leaves the tutees in a constant interactional and contextual quest in the area of awareness and the self. From this and the arguments signalled above we can infer that learning in tutoring is enactment of knowledge while coordinating speech rather than mere knowledge transmission. This claim is founded on the following arguments:

1. Learning through conversing is, following Clark's concept of embedded mind (Clark, 2001, 2008; Hutchins, 1995), distributed by being off-loaded into the environment. This environment is co-constructed by tutor and tutee who co-ordinate a collaborative and co-operative dialogical relationship in such a way as to provide space for the construction of shared meanings. As a result, learning through dialoguing leads to a collective shared outcome.

2. Learning, as a result of cognition is embodied or shaped by the aspects of the entire body.

3. Learning in tutoring is enacted. We find Bateson's (1972) emphasis on the act of knowing (as opposed to knowledge) applicable here. Any conscious knowing is in action (Davis, 2013) and the action we observe in tutoring is predominantly languaging in co-operation where shared meanings are constructed. In this way a tutoring conversation is transformative, as agents contribute to creating the learning space and both invest in the creation of new knowledge based on their individual inventory of facts, skills and competencies. Focusing on the transforming effects of tutoring for students, we find that the dialogical space built by the tutor and the tutee in their mutual linguistic interaction becomes a location of shared meanings and understanding where learning by appropriation is essentially through language use.

In thinking about tutor-tutee as a dyadic dynamical cognitive system, we turn away from the individual to the dialogical focus. Humans are what they are because of the history of events which each has experienced in life. 
Here dialogicality becomes an effective educational mode in which we observe individual processes of internalising personal experience of thinking and reflection and the constituting of social and cultural practices over time. The paradigm in which the idea is discussed is inspired by Bakhtinian and Vygotskian, considered in terms of its sociality. This positions educational practice as an activity which two languaging agents partake in their meaning-making processes. As such, dialogue in the educational setting is an example of talk-in-interaction with a mediating role in thinking and understanding.

In tutoring the social and the individual converge in dialoguing activity based on Socratic questioning, as well as Freire's (1997) philosophy of egalitarian and non-systemic form of education, where both the teacher and the student (tutor and tutee) co-ordinate each-other's communicative actions in their mutual process of meaning-making. As we have already intimated, the aim of the questions is to reveal possible contradictions and inconsistencies in the student's reasoning by putting them in perspective. This attitude allows the dialogue to become the environment for the process of reflection, with possible insights and new understanding of the issue discussed as the outcome. The social and organizational arrangement in tutoring is characterised by a mutually inclusive educational relationship where the tutor takes on the role of a facilitator or coordinator of the learning process while the student becomes an active participant contributing perspectives and modes of thinking in relation to the subject. The aim here is to challenge the student's thinking paradigms and viewpoints in order to stimulate him/her towards becoming a more critical researcher and actor on his/her own educational path (Freire, 1985). The transformative value of dialogue in the educational setting lies in its identity-constructing otential, which draws parallels to the relationship as that of being and becoming. In other words, by entering the social context of a dialogue, we secure a context for sense-making processes which in effect prove to be transformative.

\section{The significance of dialogue and languaging in tutoring as a case of transformative learning}

The focus on dialogue as the pivot for transformative learning does not seem to be new. It can be traced back to the concept of re-languaging in therapy which consists in re-cognising and re-structuring one's knowledge by languaging (Hall, 1996). In this way language constitutes a space where experience is reshaped (Barnes, 1992; Vygotsky, 1978; Wells, 1999) as "rendering thinking into speech is ... a process through which thinking reaches a new level of articulation" (Smagorinsky, 1998, 172-3). A pertinent element contributing to the development of our argument can be found in 
Swain's (2006) idea of 'talking-it-through' which, in her view, engenders new understanding and insight. In this we agree with Swain who builds on Wertsch by stating that languaging is an activity through which a learner exercises agency; it is a process of "making meaning and shaping knowledge and experience" (Swain, 2006, p. 98). Despite the unquestionable value of Swain's contribution which orientates our attention again towards language (understood as 'speech') as a domain with the potential to change in consciousness, her understanding of languaging still seems to be limited and insufficient for our purposes - largely because she loses sight of the copresence and co-operation of two agents in the construction of dialogue as a learning environment. Much as dialogue is a form of human behaviour, it should be stressed that it features two interactants involved in cognitive processes. In this manner and by mutual communicative dependence, they co-construct speech and, by extension, new knowledge. Sidorkin confirms our stance in the statement that "[t]he most important things in human lives happen between human beings, rather than within or without them" (Sidorkin, 1999, p. 11).

As Linell (1998) concludes, language is an activity which happens between the dialoguing agents. Similarly, Cowley (2011) argues that for two individuals interlocked in dialogue, language is a co-operative mode used in social situations. It is a coordinated communicative activity where wordings play a part. Consequently, language understood as an activity reveals a vital aspect of the tutor-student/tutee dyad substantially affecting its quality and effectiveness as a trigger of cognitive behaviour change. In and through language a space is created which serves the tutor and tutee in their own sensemaking processes.

A tutoring dialogue, naturally built on languaging as it is, becomes a space where the synergy resulting from two speakers establishing a cognitive domain prompts transformative learning. In other words, the tutor and the tutee exhibit languaging behaviour whereby they contribute to their individual sense-making processes, in dialogical transformative learning, as in all other types of conversation. With coordination as the distinguishing factor, we bring to the fore embodied interaction between individuals, which occurs not only in and through language as a system but also as a sensorimotor activity (the inventory of body moves, gestures, mimicry which as a whole contribute greatly to mutual comprehension). As a consequence of approaching language in the way specified above, we should present a tutoring conversation as an example of transformative educational practice which originates in the fact that the tutor and tutee engaged in language environment form a consensual domain of coordinated situation-specific interactions. In assigning language as the key factor contributing to cognitive change and learning, we postulate a developing interest in what happens between two conversing agents rather than what each says and how it is said. 
Sense-making manifests itself in the relationship between the languaging learner and his/her situational context and is determined by the value which the languaging relationship holds for that learner. This can be observed in pivotal moments of tutoring conversation which are instigated by the tutor's question, paraphrase or tutee's words echoed by the tutor.

\section{Dialogical learning based on collectivity in tutoring - confirmation from two case studies}

Language is clearly used here as an arena for collective thinking which consequently affords the development of the individual's intellectual ability (cf. Mercer, 2002). What we understand by "collectivity" is constructing socially structured knowledge in the process of interactivity (Steffensen, 2013) as mentioned above. Intertwined conversationally with their respective ecological being, the tutor and the student/tutee become inextricably linked with the cognitive dynamics of their conversation. In the context of tutoring, therefore, by engaging in collective thinking the individuals examine a problem together from a number of perspectives. This process involves drawing on knowledge from their experience, be it personal, physical, social, ethical, aesthetic etc.. Both tutor and student/tutee are urged to engage their entire mind, thus changing what separates them into an interactive relationship, as in Brown and Lambert (2013).

In the two examples which follow we attempt to demonstrate how learning occurs collectively in a dialogue. Each excerpt is a fragment of a video recording from a ninety-minute tutoring session, each provided for a different student. Both students independently volunteered to participate in a series of seven such sessions and consented to being recorded. Their tutor is an experienced academic teacher with additional five-year experience as a tutor. The symbols used in the transcripts follow the system outlined by Atkinson and Heritage (1984). The notations on the left signify the following: TP - tutor's line in Polish, TE - tutor's line in English translation, SP - student's line in Polish SE - student's line in English translation.

The fragment in Example 1 features a twenty-two-year-old male BA student described by his tutor as "an ambitious but rather struggling type". He motivated his participation in the tutoring process by pointing to his interests in the mechanisms of conversation. What we can observe here is the two participants discussing the metaphor presenting conversation as a racetrack proposed in a video which the tutee watched as homework. This is the fourth meeting in a series of seven.

Example 1

1 TP: To jest kiedy ja podejmuje refleksje w rozmowie ta: : k? 
TE: This is when I reflect in a conversation, isn't it?

3 SP: ( (mouth click)) Właśnie nie wiem bo gdyby: (.) pan podjał refleksję w rozmowie: (.) >nie to może się pan po prostu zatrzymać. Tak ((chin down)) (.) Uhm (0.2) Ale gdyby było na odwrót to by ten ( ) się tylko wydłużył (0.2) Jeśli dobrze rozumiem.

SE: ((mouth click)) This is what I don't know because if: (.) you reflected in a conversation: (.) >no then you can just stop. Yes ((chin down)) (.) Uhm (0.2) But if this was the other way round then this ( ) would only get longer (0.2). If I am correct.

TP: Jeśli biegniemy tak? A jeśli em: : uznamy to że kończymy budowanie metafory (.) a zaczynamy rozumieć ta metafore JUż jako rozmowe=

$\mathrm{TE}$ : If we are running, right? And if em: : we find it that we are finishing building the metaphor (.) and we are beginning to understand this metaphor ALREADY as a conversation=

SP: =no to to jest po prostu ( )

SE: then this is simply ( )

TP: To w jakim sen bo to jest paradoks tutaj, prawda? Pytanie KTO się miałby zatrzymać w tym momencie. Czy ten który idzie z tyłu: : czyli już troszeczkę odpada z rozmowy: czy ten który biegnie z przodu i nadaje jej ton.

TE: This is to a po because we have a paradox here, don't we? The question is wHO should stop at this point. The one walking behind: : so he stays a little bit out of the conversation: or the one running at the front and setting the tone for it.

7 SP: ((mouth click)) Osoba musiałaby przestać gadać ( (both hands move up and down simultaneously)) a ta druga osoba musiałby po prostu (.) ( ) to co zostało powiedziane.

SE: ( (mouth click)) The person would have to stop talking ( (both hands move up and down simultaneously), and this other person would have to simply (.) ( ) what has been said 
TE: So who is reflecting in this situation?

9 SP: Osoba słuchajaca. Osoba mówia:ca: : (.) czeka.

SE: The listener. The spea:ker: (.) is waiting.

10 TP: Uhm. Czyli w tej w tym w tym w tej tej sytuacji która pan tu zaproponował wykładowca student kto by był kim.

TE: Uhm. So in this in this in this situation which you have proposed here of teacher student who would be whom.

11 SP: Znaczy student by: :::ł ( )

$\mathrm{SE}:$ I mean the student wa::::s ( )

12 TP: Czyli:: $\uparrow(0.2)$ >obydwaj się zatrzymali<.

TE: So: : $\uparrow(0.2)$ >they both stopped<

13 SP: >No niekoniecznie bo mogli na przykład profesor może sobie zrobić rozgrzewke< y::m pisza:c na tablicy: : nie wiem jakieś objaśnienia czy ( ). To już niekoniecznie zaczynajac [( )]

SE: >Well not necessarily because they could for instance the professor might have a warm-up< $y:$ :m writi:ng on the board: : I don't know some explanations or ( ). This is not necessarily beginning [( ) ]

14 TP: [Czyli] idzie dale:j? tylko wolnie:j?

TE: [So] he goes on walki:ng? Only more slow:ly?

$15 \mathrm{~S}: \mathrm{uhm}$

16 TP: TP: A ten drugi stoi? (0.3) bo podjał refleksję.

$\mathrm{TE}$ : And the other one is standing? (0.3) because he has reflected upon something.

$17 \quad(0.4)$

18 SP: Nie (.) bo biegajac właśnie on podejmuje refleksje mi się (.) kurcze. ${ }^{\circ}(0.4)$ No >tak troszeczke chyba to sie< nie ima ze soba.

$\mathrm{SE}$ : No (.) because when running he is reflecting upon as I (.) oh dearo (0.4) Well >yes this I reckon doesn't< stick.

19 TP: Nie ima się ze soba?

TE: Doesn't stick?

We can observe the two participants following their own lines of thinking. Although at times they do agree, the student/tutee tries to develop his argument. This becomes particularly clear with his verifying commentary "if I understand 
it correctly". The tutor invites the student to explain some issues, at the same time wondering and asking himself questions such as "WHO should stop". The responses he receives from the student are only at times directly relevant to the content of these questions. The frequent inter-turn and intra-turn pauses and 'thinking moments' may suggest the reflective stance adopted when co-constructing a solution to the problem posed by the metaphor they are trying to apply to the issue that is the object of their interest. The pivotal moment in their discursive collectivity would appear to come with the student's words in line 18 "(.) kurczę $e^{0 "}\left[(\right.$.$\left.) oh dear { }^{\circ}\right]$. The whole impetus of his reasoning from line 13 sees its critical moment in the four-second silence (line 17) further concluded by the quick cue "No >tak troszeczkę chyba to się< nie ima ze sobą" [Well >yes this I reckon doesn't $<$ stick] (line 18). His conclusion and the tutor's subsequent acknowledgment of the discovery in line 19 seems a concise summation of their co-operative interaction.

The mention of 'me as an individual' in students' reports echoes the element of identity formation present when new knowledge is constructed and implies the process of identity building with effects in establishing new epistemic beliefs (e.g., Cano 2005). Epistemic beliefs are a rather complex construct. Due to the limited space and scope of this text we will not cover the multitude of conceptualisations and models of epistemic beliefs. Instead, we will be more interested in how the student's/tutee's beliefs undergo transformation in the course of tutoring conversation. One example of this process can be found in Example 2 which features a thirty-fouryear-old male $\mathrm{PhD}$ student whose tutoring process revolved around the theme of the discourse of political propaganda. In this his sixth and penultimate session, we can witness his endeavour to design a methodology for his $\mathrm{PhD}$ research. The tutee comes to a dead end where he needs a method to prove the validity of the theoretical model of persuasion which he has built in the course of his tutorials. The student's belief is that his only option is to refer to past research in the hope that a similar study area has already been investigated. His idea is to use "books on critical discourse analysis" but he seems unconvinced about this solution and finds it limiting.

Example 2

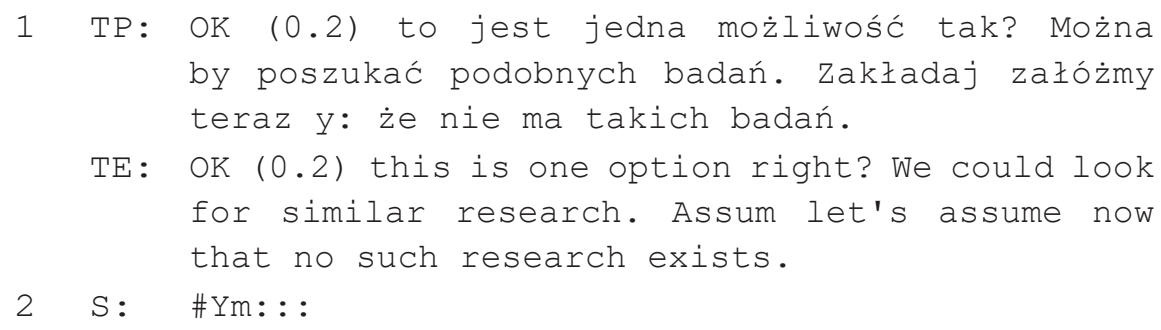


3 TP: W jaki sposób moż moglibyśmy (.) w swoich ym $y: m$ ograniczonych zasobach stwierdzić czy działa dane dany zarzut perswazji narzedzie pers perswazji czy nie? > Innymi słowy< po czym poznamy?

TE: How cou could we (.) within our yhm y:m limited resources conclude that a particular allegation about persuasion tool of persuasion works or doesn't work? >In other words< how shall we know?

4 $(0.33)$

5 SP: ((grunt)) < ${ }^{\circ} \mathrm{N}:$ ie wiem: $\uparrow>$

$\mathrm{SE}: \quad($ (grunt)) <oI d:on't know: $\uparrow>$

6 TP: A po czym poznać że cokolwiek działa. Weźmy (.) no weźmy zegar. Albo (.) proszę (.) podać jakiśs przykład jakiegoś jakiejśs rzeczy która działa (.) Może być proces może być <urządzenie:> cokolwiek.

TE: And how do we know if anything works. Let's take (.) well let's take a clock. Or (.) can you (.) please give us an example of a thing which works (.) This can be a process this can be a <device:> anything.

$7 \quad(0.13)$

8 SP: ((mouth click and sigh)) To wtedy e: : : potrzebujemy takiej (0.4) m: : (0.13) TAKIM systemem obadania tak? (0.3) Woda się gotuje.

SE: ((mouth click and sigh)) So then e: : : we need such a (0.4) m: : (0.13) with SUCH a system of oxamination right? (0.3) Water is boiling.

9 TP: Ok (.) czyli coś działa.

TE: Ok (.) so something works

10 SP: Tak, coś działa, jak t: :

SE: Yes, something works like t: :

11 TP: Czajnik.

TE: A kettle. 


\section{SP: Tak czajnik. 'Woda się gotuje, tak? GARNEK z WODA na ogniu. Najpierw (0.2) dotykasz jest zimne: : ○:: Ogień działa:- \\ SE: Yes a kettle. 'Water is boiling, right? A POT with WATER on heat. First you touch and it's

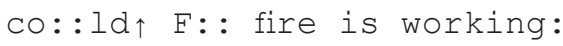

\section{TP: A: : :}

$\mathrm{TE}: \mathrm{A}::$ :

What is notable in this extract is the shift in student's beliefs regarding the relation to the evolving nature of knowledge and its source. This process is facilitated by the conversation-specific strategies employed by the tutor, for example paraphrasing or metaphor building. To be more precise, in line 1 the tutor invites the student/tutee to follow an alternative path of reasoning. Much as the first attempt apparently fails (the thirty-three-second conversational pause), the second take on the road block turns out to be more successful and the tutor's reformulation results in a thirteen-second period of silence followed by the student engaging in figurative thinking and building an analogy which works as a mental scaffolding for both him and the tutor in the subsequent stages of the conversation. From this point onward, we can see the student/tutee entering an 'instructional' mode as he narrates his own process of adapting to a new perspective. This begins in line 12 where he clarifies his new idea. It seems that by offering sufficient sense-making space, the two periods of silence (lines 2 and 5) were crucial to a change in what may be classified as the student's epistemic beliefs. Building on this, he assumes responsibility and produces a satisfactory solution. The explanations the student proposes are emphasised by the phonological prominence given to some wordings (e.g., lines 8 and 12). These apparently provide him with 'hooks' on which to hang his reasoning. The tutor's stance as assistant or facilitator allows the student/tutee to remain open to new paradigms of thinking, which finally permits him to construct a satisfactory solution.

What happens in tutoring talk therefore echoes what Littleton and Mercer (2013) refer to as educational dialogue. The socio-cultural constructivist path undertaken in their research and observations alerts us to those elements of tutoring which contribute to its overall efficacy. Although the authors are interested exclusively in the nature and significance of classroombased educational dialogues for children's development and learning, their findings are also applicable and relevant to the current discussion. The major value of their findings is the focus on those functions of talk which can be employed in a dialogical educational approach. These include taking stock of the student's initial knowledge and building on that by encouraging reflective and critical thinking. This aids students' model ways of arguing and reasoning and perceives their own learning trajectory. 
In the examples above, we note the presence of all three features mentioned by Mercer (2000, 2013). On the one hand both tutor and student/tutee are involved in an argument, while on the other they seem to draw on what is available in an endeavour to construct 'new knowledge'. The tutor can be seen as an instigator and a facilitator in the tutee's process of thinking aloud in which the latter discloses his path taken to reach the desired solution. Dialogue in tutoring appears as a type of exploratory talk in that it invites both participants to the domain of self-regulated learning with metacognition as the guiding factor.

A certain weight is lent to our observations by Schommer-Aikins's findings (Schommer, 1998; Shommer-Aikins, 2002 and 2008). These note the positive significance of the simultaneous occurrence of three aspects (which we will refer to as 'conversational parameters') of the preparatory teacher-student dialogue:

1. elaboration where building on, evaluating and clarifying a previous contribution was invited or provided;

2. querying where the teacher challenged/ rejected/disagreed with previous student contribution;

3. participation where students were invited to engage with each other's ideas; in tutoring this could translate as tutor-student working jointly on a topic considering their mutual points of view.

Schommer-Aikins confirms the interdependence and synergy between these parameters by noting that low frequency of Elaboration and Querying negatively influenced the appearance of Participation. We suggest that the cognitive results of tutoring referred to by the students in Karpińska-Musial's study stem from the simultaneous presence of the three parameters in tutor-tutee dialogue. In our samples we can discern the parameter of Elaboration in the predominant part of Extract 1 (with lines 1-3 and 6-7 being central to what happens in line 18). It is at this juncture that the student comes to a conclusion founded on the parameter of Participation. By engaging with the tutor's contributions and his own utterances, the student becomes constructively critical of the theory under discussion. The tutor's Querying in line 6 of Extract 2 paves the way for the occurrence of Participation in that the student proposes his own figure in line 8 as a springboard to the idea generated further in the dialogue. From this moment both participants begin building on their previous contributions. It can therefore be concluded that tutoring with its conversational tools and effects seems to neatly fall into the social-cognitive models of self-regulated learning (cf. Neber\&Schommer-Aikins, 2002) understood as a process where the student/tutee takes control of his/her own educational process, while provided with the tools to evaluate his own learning and behaviour (Ormrod 
2009, p. 105). Therefore we infer that the 'togetherness' sensed by students may stem from the act of collaborative problem-solving, as in Extract 2. Thinking of learning in tutoring as an epitome of a participatory educational process leads us to consider dialogue as the crux of the method and the ultimate source of its effectiveness.

\section{Concluding remarks}

In this paper learning is viewed as a result of evolving interaction on the part of the learner with his/her environment through the medium of languaging. In this context, learning in a dialogical tutor-tutee situation is a distributed, embodied and enacted meaning-making process rather than mere 'sending' and 'receiving' of substantive information. By presenting tutoring as a transformative educational practice, we must see it as part of participatory culture "in which members believe their contributions matter, and feel some degree of social connection with one another" (Jenkins, et al., 2006, p. 3).

Tutoring described in this perspective compels us to rethink and reconsider our views on learning, knowledge and expertise. It is a horizontal relationship where cognition appears as dialogical. This makes it stand in contrast to the well-established and widespread culture of dominance and monological authoritarian teaching in the global educational system. As such it becomes an attractive offer to those who feel committed to the idea of participatory culture. The enactivist stance we adopt here offers tools which help us grasp the hidden and complex interdependencies between knowledge, mind, society, experience and the autonomy of the individual. The statement that cognition takes place in an interaction between the individual and his/her environment or another individual in such a way that both parties in the process are transformed sheds some light onto the autonomous dynamics which arise in an interaction between the tutor and the tutee. The change we mention in this paper concerns the self and is what Davis (1996) calls a "transformative process". This change however, is not Piagetan in the sense that it happens to the self. Instead, since the self is a network of different relationships, any change enacts a different self.

\section{References}

Atkinson, J.M., Heritage, J. (Eds.). (1984) Structures of social action: Studies in conversation analysis. Cambridge: Cambridge University Press. doi: https://doi.org/10.1017/S0022226700011464

Barnes, D. R. (1995). From communication to curriculum. Portsmouth, NH: Boynton/Cook Publishers. 
Bateson, G. (1973). Steps to an ecology of mind: Collected essays in anthropology, psychiatry, evolution and epistemology. London: Paladin, Granada.

Brown, V. A., Lambert, J. A. (2013). Collective learning for transformational change: A guide to collaborative action. New York, NY: Routledge.

Butler, E. A., Randall, A. K. (2013). Emotional coregulation in close relationships. Emotion Review, 5(2), 202-210. doi:https://doi. org/10.1177/1754073912451630

Cano, F. (2005). Epistemological beliefs and approaches to learning: Their change through secondary school and their influence on academic performance. British Journal of Educational Psychology, 75, 203-221.

Clark, A. (2001). Mindware: An introduction to the philosophy of cognitive science. New York, NY: Oxford University Press.

Clark, A. (2008). Pressing the flesh: A tension in the study of the embodied, embedded mind. Philosophy and Phenomenological Research, 76(1), 37-59.

Cowley, S. (2010). Signifying bodies: Biosemiosis, interaction and health. Braga: The Faculty of Philosophy of Braga, Portuguese Catholic University.

Cowley, S. (2011). Taking a language stance. Ecological Psychology, 23(3), 185-209. doi: https://doi.org/10.1080/10407413.2011.591272

Cowley, S. (2015). Verbal patterns: taming cognitive biology. In E. V. Vel'mezova, K. Kull, S. Cowley (Eds). Biosemiotic perspectives on language and linguistics. London: Springer. doi:https://doi.org/10.1007/9783-319-20663-9_7

Cranton, P. (1992). Working with adult learners. Toronto, Ontario: Wall \& Emerson.

Cranton, P. (1994). Self-directed and transformative instructional development. Journal of Higher Education, 65(6), 726-744. doi: https://doi.org /10.1080/00221546.1994.11774748

Davis, B. (1996). Teaching mathematics: Towards a sound alternative. New York, NY: Garland Publishing Inc.

Davis, B. (2013). Teaching mathematics: Toward a sound alternative. New York, NY and London: Taylor and Francis.

Davis, A. B., Sumara, D. J., Kieren, T. E. (1996). Cognition, co-emergence, curriculum. Journal of Curriculum Studies, 28(2), 151-170.

De Jaegher, H., Di Paolo, E. (2007). Participatory sense-making: An enactive approach to social cognition. Phenomenology and the Cognitive Sciences, 6(4), 485-507. doi: https://doi.org/10.1007/s11097-007-9076-9

Elias, D. (1997). It's time to change our minds: An introduction to transformative learning. ReVision, 20(1), 2-6.

Fogel, A. (2009). The psychophysiology of self-awareness: Rediscovering the lost art of body sense. New York, NY: W.W. Norton. 
Freire, P. (1997). Pedagogy of the heart. New York, NY: Continuum.

Freire, P. (2007). The politics of education: Culture, power, and liberation. South Hadley, MA: Bergin \& Garvey.

Fuchs, T., De Jaegher, H. (2009). Enactive intersubjectivity: Participatory sense-making and mutual incorporation. Phenomenology and the Cognitive Sciences, 8(4), 465-486. doi: https://doi.org/10.1007/s11097-009-9136-4

Grabove, V. (1997). The many facets of transformative learning theory and practice. In: P. Cranton (Ed.), Transformative learning in action: insights from practice. New directions for adult and continuing education. no. 74, (pp. 89-96). San Francisco, CA: Jossey-Bass. doi: https://doi.org/10.1002/ ace.7410

Hall, L. M., (1996). Languaging: The linguistics of psychotherapy. How language works psycho-therapeutically: an exploration into the art and science of "therapeutic languaging" in four psychotherapies (neurolinguistic programming, reality therapy, rational-emotive behavior therapy, logotherapy). Using general-semantic formulations. Unpublished PhD diss. The Union Institute.

Hutchins, E. (1995). Cognition in the wild. MIT Press.

Jenkins, H., Clinton, K., Purushotma, R., Robison, A., Weigel, M. (2006). Confronting the challenges of participatory culture: Media education for the 21st century. Washington, DC: The John D. and Cathering MacArthur Foundation.

Karpińska-Musiał, B. (2016). Edukacja spersonalizowana $w$ uniwersytecie: Ideologia, instytucja, dydaktyka, tutor. Kraków: Wydawnictwo LIBRON Filip Lohner.

Linell, P. (1998). Approaching dialogue: Talk, interaction and contexts in dialogical perspectives. Amsterdam, Philadelphia, PA : J. Benjamins Pub. Co. doi:https://doi.org/10.1075/impact.3

Littleton, K. N. Mercer (2013). Educational dialogues. In K. Hall, T. Cremin, B. Comber, and L.C. Moll (Eds), International handbook of research on children's literacy, learning and culture (pp. 291-303). Oxford: WileyBlackwell.

Marková, I. (2003). Dialogicality and social representations: The dynamics of mind, Cambridge: Cambridge University Press.

Maturana, H. R., Varela, F. (1988). The tree of knowledge. Boston, MA: Shambhala New Science Library.

Matusov, E. (2009). Journey into dialogic pedagogy. Hauppauge, NY: Nova Publishers.

Matusov, E. Miyazaki, K., (2014). Dialogue on dialogic pedagogy. Dialogic pedagogy vol. 2. Retrieved from https://dpj.pitt.edu/ojs/index.php/dpj1/ issue/view/4. 
Mercer, N. (2000). Words and minds: How we use language to think together. London: Routledge. doi:https://doi.org 10.1016/S0346251X(02)00044-1

Mercer, N. (2002) Developing dialogues. In G. Wells, ,Claxton, G. L. (Eds), Learning for Life in the 21st Century: sociocultural perspectives on the future of education (viii ed.) (pp. 141-153). Oxford: Blackwell. doi:https:// doi.org/10.1002/9780470753545.ch11

Mercer, N., Littleton, K. (2007). Dialogue and the development of children's thinking. New York, NY: Routledge.

Mezirow J. (1991). Transformative dimensions of adult learning. San Francisco, CA: Jossey-Bass. doi:https://doi.org/10.1177/074171369204200309

Mezirow, J. (1997). Transformative learning: theory to practice. New Directions for Adult and Continuing Education, 74, 5-12.

Mezirow J. (2000). Learning to think like an adult. core concepts of transformation theory. In Mezirow \& Asscociates (Eds.), Learning as transformation. critical perspectives on a theory in progress (pp. 3-33), San Francisco, CA: Jossey-Bass.

Mezirow, J. (2003) Transformative learning as discourse. Journal of Transformative Education, 1, 58-63.

Neber, H., M. Shommer-Aikins (2002). Self-regulated science learning with highly gifted Students: The role of cognitive, motivational, epistemological, and environmental variables. High Ability Studies 13(1) 59-74. doi:https://doi.org/10.1080/13598130220132316

Neumann, M. \& Cowley, S. (2013). Human agency and the resources of reason. In S. Cowley, F. Vallée-Tourangeau, (Eds.), Cognition beyond the brain (pp. 13-30). London: Springer. doi:https://doi.org/10.1007/978-1-44715125-8_2

Ormrod, J. E. (2009). Essentials of educational psychology. Upper Saddle River, NJ: Pearson Education Inc.

Schommer, M. (1998). The role of adults' beliefs about knowledge and learning in school, work, and everyday life. In M. C. Smith,T. Pourchot (Eds.), Adult learning and development: Perspectives from educational psychology (pp. 127-143). Hillside, NJ: Lawrence Erlbaum Associates.

Schommer-Aikins, M. (2002). An evolving theoretical framework for an epistemological belief system. In B. Hofer, P. Pintrich (Eds.) Personal epistemology: Th psychology of belief about knowledge and knowing (pp. 103-118). Hillsdale, NJ: Lawrence Erlbaum.

Schommer-Aikins, M. (2008). Applying the theory of an epistemological belief system to the investigation of students' and professors' mathematical beliefs. In K. Myint Swe (Ed.), Knowing, Knowledge and Beliefs: Epistemological Studies Across Diverse Cultures (pp. 303-323). Netherlands: Springer.

Sidorkin, M., (1999). Dialogue with evil. Faculty Publications. Retrieved from https://digitalcommons.ric.edu/facultypublications/19. 
Smagorinsky, P. (1998). Thinking and speech and protocol analysis. mind, culture, and activity. 5(3), 157-177. doi:https://doi.org/10.1207/ s15327884mca0503_2

Steffensen, S. V. (2013). Human interactivity: Problem-solving, solution-probing and verbal patterns in the wild. In S. J. Cowley \& F. Vallée-Tourangeau (Eds.), Cognition beyond the brain: Computation, interactivity and human artifice (pp. 195-221). Dordrecht: Springer. doi: https://doi. org/10.1007/978-1-4471-5125-8_11

Sumara, J. D., Davis, B. (1997). Enactivist theory and community learning: toward a complexified understanding of action research. Educational Action Research, 5(3), 403-422.

Swain, M. (1985). Communicative competence: some roles of comprehensible input and comprehensible output in its development'. In S. Gass, C. Madden, (Eds.) Input in second language acquisition. Rowley, MA: Newbury House.

Swain M. (2006). Languaging, agency and collaboration in advanced second language proficiency. In H. Byrnes. (Ed.), Advanced language learning: The contribution of Halliday and Vygotsky (pp. 95-108). LondonNew York: Continuum.

Thibault, P. J. (2011). First-order languaging dynamics and second-order language: The distributed language view. Ecological Psychology, 23(1), 1-36. doi:https//doi.org/10.1080/10407413.2011.591274

Varela, F. J., Thompson, E., Rosch, E. (1991). The embodied mind: Cognitive science and human experience. Cambridge, MA: MIT Press.

Vygotsky, L. S. (1978). Mind in society: The development of higher psychological processes. Cambridge, MA.: Harvard University Press.

Wells, C. G. (1999). Dialogic inquiry: Towards a sociocultural practice and theory of education. New York, NY: Cambridge University Press. 